\title{
Formation of closed mesopores in boehmite during the phase transformation of gibbsite under hydrothermal conditions
}

\author{
Svetlana R. Egorova ${ }^{1}$ - Aliya N. Mukhamed'yarova ${ }^{1}$. \\ Asiya Z. Kurbangaleeva ${ }^{1} \cdot$ Yuqing Zhang $^{1,2} \cdot$ Alexander A. Lamberov $^{1}$
}

Received: 14 March 2018/Accepted: 10 June 2018/Published online: 23 June 2018

(C) The Author(s) 2018

\begin{abstract}
We report a study of the phase transformation of gibbsite-boehmite under hydrothermal treatment in aqueous suspension and under the "dry steam" conditions at $\mathrm{T}=180-210^{\circ} \mathrm{C}$ and $\mathrm{P}=1.0-1.9 \mathrm{MPa}$ for $30-540 \mathrm{~min}$. It is the first time that the closed mesopores formed during the splicing of large crystals in which water is encapsulated in an amount of up to $1.8 \%$ of the masses are found in boehmite. The spread of closed mesopores by the diameters depends on the conditions of hydrothermal treatment: in the aqueous suspension the mesopores are of the diameters less than $4 \mathrm{~nm}$, under conditions of "dry steam"-in the range of 4-6 nm and 10-200 nm. With those closed mesopores, it possible to use boehmite in various fields of chemistry and technology for the encapsulation and transport of solutions containing the active components and connections.
\end{abstract}

Keywords $\gamma$-Alumina $\cdot$ Boehmite $\cdot$ Gibbsite $\cdot$ Hydrothermal treatment $\cdot$ Heat treatment

Electronic supplementary material The online version of this article (https://doi.org/10.1007/s11144018-1431-z) contains supplementary material, which is available to authorized users.

Svetlana R. Egorova

Svetlana.Egorova@kpfu.ru

1 Alexander Butlerov Institute of Chemistry, Kazan Federal University, St. Kremlin, 29/1, Kazan, Russian Federation 420008

2 Institute of Chemistry, Chemical Engineering and Materials, Heilongjiang University, St. Xuefu, 74, Harbin 150080, China 


\section{Introduction}

Boehmite $(\gamma-\mathrm{AlOOH})$ is an important mesoporous [1] material; due to the high specific surface, pore volume and presence of mesopores it is used as adsorbent [2], catalyst carrier [3], and intermediate phase in the production of alumina carriers, petrochemical and petroleum processing catalysts [4], membranes and filters [5], a component of toothpastes, enveloping and adsorbing agents in medicine. The parameters of the mesoporous system determine the adsorptive capacity of boehmite with respect to toxic organic and inorganic compounds in the wastewater treatment and in solving environmental problems [6].

The dimensions of the crystals and the way they are packaged are very important for the functional materials obtained from boehmite; they affect its porous system, the temperatures of phase transitions into aluminum oxides. There are several types of boehmite: pseudoboehmite of the composition $\gamma$-AlOOH$\cdot \mathrm{nH}_{2} \mathrm{O}(\mathrm{n}=0.3-1.0)$ with crystallite sizes of 2.5-3.5 nm (the specific surface area $S_{p}$ up to $450 \mathrm{~m}^{2} / \mathrm{g}$ and the pore volume $\mathrm{V}_{\mathrm{p}}$ up to $0.80 \mathrm{~cm}^{3} / \mathrm{g}$ ) [7]; fine crystalline boehmite of the composition $\gamma$-AlOOH$\cdot \mathrm{nH}_{2} \mathrm{O}(\mathrm{n}=0.0-0.2)$ with crystallite sizes of $11-13 \mathrm{~nm}$ $\left(S_{p}=220-250 \mathrm{~m}^{2} / \mathrm{g}, \mathrm{V}_{\mathrm{p}}=0.58-0.60 \mathrm{~cm}^{3} / \mathrm{g}\right)$ [8, 9]; well crystallized boehmite of the composition $\gamma$-AlOOH$\cdot \mathrm{nH}_{2} \mathrm{O}(\mathrm{n}=0.0-0.2)$ with crystal sizes up to $80-140 \mathrm{~nm}$ $\left(\mathrm{S}_{\mathrm{p}}<150 \mathrm{~m}^{2} / \mathrm{g}, \mathrm{V}_{\mathrm{p}}<0.15 \mathrm{~cm}^{3} / \mathrm{g}\right)$ [10]. Parameters of the boehmite porous system are varied by the method and conditions of its production.

Precipitation from acidic or alkaline solutions of aluminum compounds [11, 12], hydrolysis of aluminum alkoxides [13, 14] produce the mesoporous pseudoboehmite with $\mathrm{V}_{\mathrm{p}}=0.26-1.00 \mathrm{~cm}^{3} / \mathrm{g}, \mathrm{S}_{\mathrm{p}}=102-354 \mathrm{~m}^{2} / \mathrm{g}$ and pore diameters of $5.3-15.2 \mathrm{~nm}$. Boehmite with $\mathrm{V}_{\mathrm{p}}=0.20-0.32 \mathrm{~cm}^{3} / \mathrm{g}, \mathrm{S}_{\mathrm{p}}=100-120 \mathrm{~m}^{2} / \mathrm{g}$ and pore diameter 11.4-15.1 nm [15-17] is obtained from amorphous precipitates of aluminum hydroxides under hydrothermal conditions. A large-crystalline nonporous boehmite with $S_{p}=3.1 \mathrm{~m}^{2} / \mathrm{g}$ and a pore diameter of $24.6 \mathrm{~nm}$ is obtained from gibbsite under the hydrothermal conditions at a temperature $\geq 150{ }^{\circ} \mathrm{C}$ $[18,19]$.

There are a few types of pores: open, deadlock and closed pores. The parameters of the former two are important in the development and synthesis of catalysts, catalyst carriers, adsorbents from hydroxides and aluminum oxides. The closed pores might be used during the synthesis to encapsulate and transport compounds or solutions containing active components, and then, for example, through the thermal decomposition of boehmite, modify the resulting aluminas or mixtures. Hollow micro- and nanostructures are used in biomedicine, as fluorescent markers, capsules for sensitive materials for drug delivery purposes. The effect of the formation of closed pores in oxo-hydroxide compounds of aluminum is described in [20] after compaction of $\gamma-\mathrm{Al}_{2} \mathrm{O}_{3}$ at high pressure using the "cold sintering" model. However, at the moment, there is almost no information about closed pores in boehmite, which can be formed during crystallization of its particles, for example, under hydrothermal treatment of gibbsite, in the scientific literature. Hydrothermal treatment is the most affordable (due to the low cost of gibbsite) and the least energy- and resource-consuming way of producing boehmite under conditions of 
"dry steam" and in suspension. However, there is no consensus on the mechanism of the phase transformation gibbsite $\rightarrow$ boehmite. On the one hand, there is a group of authors [21, 22] that favors the solid-phase transformation mechanism, on the other hand, some of them prefers the mechanism of crystallization through dissolution of gibbsite and the subsequent re-precipitation of boehmite [23-26]. The refinement of the mechanism requires detailed studies of this phase transformation.

Therefore, the purpose of this work was to establish the possibility of forming closed pores in boehmite obtained by hydrothermal treatment of large agglomerates of gibbsite $(40-180 \mu \mathrm{m})$ and parameters of the porous system that it provides, as well as to elaborate the phase transformation mechanism of gibbsite-boehmite during the hydrothermal treatment of large agglomerates.

\section{Experimental}

\section{Sample preparation}

Gibbsite $\left(\gamma-\mathrm{Al}(\mathrm{OH})_{3}\right)$ produced by ETI ALYMINUM A.S. (Turkey) is used for the synthesis of boehmite. Gibbsite is a layered mineral, crystallizes in a monoclinic syngony with unit cell parameters: $a=0.8641 \mathrm{~nm} ; b=0.5070 \mathrm{~nm} ; \mathrm{c}=0.9719 \mathrm{~nm}$; $\beta=94.54 \mathrm{deg}$, the spatial group $P 21 / n$. According to the ICDD No. 01-076-3811 card $\gamma-\mathrm{Al}(\mathrm{OH})_{3}$ crystals are described by electron diffraction $\mathrm{d}_{(002)}=0.485 \mathrm{~nm}$, $\mathrm{d}_{(110)}=0.437 \mathrm{~nm}, \quad \mathrm{~d}_{(200)}=0.433 \mathrm{~nm}, \quad \mathrm{~d}_{(112)}=0.318 \mathrm{~nm}, \quad \mathrm{~d}_{(021)}=0.245 \mathrm{~nm}$, $\mathrm{d}_{(311)}=0.239 \mathrm{~nm}, \mathrm{~d}_{(312)}=0.217 \mathrm{~nm}, \mathrm{~d}_{(023)}=0.199 \mathrm{~nm}, \mathrm{~d}_{(024)}=0.175 \mathrm{~nm}$. Boehmite is a mineral, crystallizes in a rhombic syngony with unit cell parameters: $\mathrm{a}=0.3693 \mathrm{~nm}, \mathrm{~b}=1.2221 \mathrm{~nm}, \mathrm{c}=0.2865 \mathrm{~nm} ; \beta=80.00 \mathrm{deg}$, the spatial group Amam. According to the ICDD No. 00-021-1307 card $\gamma$-AlOOH crystals are described by electron diffraction with $\mathrm{d}_{(020)}=0.611-0.612 \mathrm{~nm}, \mathrm{~d}_{(120)}=0.316 \mathrm{~nm}$, $\mathrm{d}_{(031)}=0.234 \mathrm{~nm}, \quad \mathrm{~d}_{(131)}=0.198 \mathrm{~nm}, \quad \mathrm{~d}_{(051)}=0.186 \mathrm{~nm}, \quad \mathrm{~d}_{(200)}=0.185 \mathrm{~nm}$, $\mathrm{d}_{(220)}=0.177 \mathrm{~nm}, \quad \mathrm{~d}_{(151)}=0.166 \mathrm{~nm}, \quad \mathrm{~d}_{(080)}=0.153 \mathrm{~nm}, \quad \mathrm{~d}_{(231)}=0.145 \mathrm{~nm}$, $\mathrm{d}_{(002)}=0.143 \mathrm{~nm}, \mathrm{~d}_{(251)}=0.131 \mathrm{~nm}$. According to the passport data, the concentration of $\mathrm{Na}_{2} \mathrm{O}$ in gibbsite is $0.15 \mathrm{wt} \%$. The agglomerates $(40-180 \mu \mathrm{m})$ were obtained by sieving the gibbsite powder with sieves. Hydrothermal treatment (HTT) of large aggregates of gibbsite was carried out in the temperature range from 180 to $210^{\circ} \mathrm{C}$ for $0-180 \mathrm{~min}$ in an aqueous suspension at a saturated water vapor pressure with the sampling after 10-30 min. The hydrothermal treatment was performed by a BüchiGlasUster 'Limbo li' autoclave with automated temperature and pressure control in a $450 \mathrm{~mL}$ stainless steel reactor with an alumina to water mass ratio of 1:5 and the an agitation by a stirrer at speed of $500 \mathrm{rpm}$ and the maximum autoclave filling of $70 \%$ (Fig. 1 in the Supplementary Material). The HTT of samples in the 'dry steam' conditions was carried out on the stationary mode with reactor filling of $50 \%$.

The $\mathrm{pH}$ of the initial aqueous suspension of gibbsite was 10.5 . The alkalinization of the medium is due to the release of a portion of sodium ions from the gibbsite agglomerates. Values of $\mathrm{pH} 8.0$ and 6.0 were achieved by adding to suspension the solution of acetic acid. In the course of kinetic studies the moment when the 
specified reaction temperature in the autoclave reactor was reached was considered to be the starting point. The temperature was raised to the required one for approximately $60 \mathrm{~min}$. The autoclave reactor was cooled by supplying cold water to the jacket. The temperature was lowered by $100{ }^{\circ} \mathrm{C}$ in approximately $20 \mathrm{~min}$.

\section{Sample characterization}

The appropriate phase concentrations were obtained using the thermal analysis (TA; Netzsch STA-449C Jupiter analyzer coupled with a QMS 403 Aeolos quadrupole mass-spectrometer). The TA was carried out in such a way to be able to record the thermogravimetric (TG), derivative thermogravimetric (DTG), and differential thermal analysis (DTA) curves simultaneously, conjugated with the quadrupole MAS spectrometer QMS 403 Aeolos in the range $30-1000{ }^{\circ} \mathrm{C}$ with a heating rate of $10{ }^{\circ} \mathrm{C} / \mathrm{min}$ in an argon flow. The samples were heated within the temperature range of $30-1000{ }^{\circ} \mathrm{C}$ at the uniform heating rate of $10^{\circ} \mathrm{C} / \mathrm{min}$ in an argon flow. Concentrations of aluminum hydroxides were calculated judging by the amount of the water released during the aluminum hydroxides dehydration, $\tau$.

The specific surface area $S_{B E T}\left(S_{B E T}\right.$ - a specific surface area calculated with the Brunauer-Emmett-Teller method) and the pore volume $\mathrm{V}_{\mathrm{BET}}\left(\mathrm{V}_{\mathrm{BET}}-\mathrm{a}\right.$ pore volume calculated with the Brunauer-Emmett-Teller method) were determined using a multipurpose Quantachrome Autosorb iQ analyzer. The specific surface area was calculated based on the specific surface area $0.162 \mathrm{~nm}^{2}$ and density $0.808 \mathrm{~g} /$ $\mathrm{cm}^{3}$ of a nitrogen molecule $\mathrm{N}_{2}$ in the normal liquid state. Adsorption isotherms were obtained at $196{ }^{\circ} \mathrm{C}$ after the degassing of samples at $500{ }^{\circ} \mathrm{C}$ under the residual pressure of $0.013 \mathrm{~Pa}$ (Figs. 8-15 in the Supplementary Material). The pore volume distributions over the pore diameters were calculated from the curve of desorption isotherm by using the standard Barret-Joyner-Highland mechanism. The accuracy in measuring the specific surface area was $\pm 0.5 \mathrm{~m}^{2} / \mathrm{g}$, in the pore volume $\pm 0.01 \mathrm{~cm}^{3} / \mathrm{g}$.

The measurements by scanning electron microscopy (SEM) were carried out with an EVO 50XVP electron microscope combined with an INCA 350 energydispersive spectrometer. The spectrometer resolution was $130 \mathrm{eV}$. The analysis was carried out at acceleration voltage of $20 \mathrm{kV}$ and working distance of $8 \mathrm{~mm}$.

The phase composition of the samples was studied using X-ray diffraction (XRD) method on a Shimadzu XRD-7000 advance diffractometer with $\mathrm{Cu} \mathrm{K}_{\alpha}$ radiation $(\lambda=1.5406 \AA)$.

A few peptized systems were lyophilized and solid-state ${ }^{27}$ Al MAS NMR spectra of the resulting powders were recorded. ${ }^{27} \mathrm{Al} \mathrm{NMR}$ spectra were obtained on a Bruker AVANCE-500 spectrometer operating at $130.3 \mathrm{MHz}$ using CPMAS probe and 4-mm rotors spun at $4 \mathrm{kHz}$. A total of 2000 transients were accumulated with a 5 - $\mu$ s pulse width, a 1-s delay time, a $0.1-\mathrm{s}$ acquisition time, and a $50-\mathrm{kHz}$ sweep width.

Spectra of hydrothermal treatment product mother liquor were recorded in 10-mm tubes on a Avance II 500 spectrometer operating at $130.3 \mathrm{MHz}$. Chemical shift were referenced to a $1 \mathrm{M} \mathrm{Al}\left(\mathrm{H}_{2} \mathrm{O}\right)_{6} \mathrm{Cl}_{3}$ solution. While recording the spectra rectangular (broadband) pulses duration $8.0-\mu \mathrm{s}$ and $80 \mathrm{~W}$ power (angle of 
rotation $<90^{\circ}$ ) were used; the relaxation delay was $1 \mathrm{~s}$. The number of accumulations was $400 / 800$, the width of the spectrum was $504.8 \mathrm{ppm}$. For digital processing digital exponential filtering with a constant $\mathrm{LB}=3 \mathrm{~Hz}$ was applied. The samples were a mixture of test solutions $(550 \mu \mathrm{l})$ with $50 \mu \mathrm{l}$ of heavy water $\left(\mathrm{D}_{2} \mathrm{O}\right)$ added to stabilize the field along the deuterium resonance line. The absolute concentration of "NMR-visible" aluminum in the samples was estimated by a calibration curve (integral vs molar concentration) established from a set of standard $\mathrm{Al}\left(\mathrm{H}_{2} \mathrm{O}\right)_{6} \mathrm{Cl}_{3}$ solutions measured under the same experimental conditions. NMR spectra were acquired at room temperature.

The infrared spectra of the samples were recorded using by BRUKER VERTEX 70 instrument. The measurements were carried out at room temperature. Samples were compressed into tablets with $\mathrm{KBr}$; after the survey spectra with a resolution of $1 \mathrm{~cm}^{-1}$ averaged over 128 scans were obtained.

\section{Results and discussion}

According the XRD, the product of gibbsite hydrothermal processing (HTT) in all modes is boehmite (Fig. 1b-e). It is showed in Fig. 1a that unconverted gibbsite and formed boehmite are present in the gibbsite $\mathrm{HHT}$ of $\gamma-\mathrm{Al}(\mathrm{OH})_{3}$ at $\mathrm{T}=180{ }^{\circ} \mathrm{C}$, $\tau=180 \min$ ( $\tau$-treatment duration), $\mathrm{pH} 10.5$ (Fig. 1a).

Dependences of boehmite content on the duration of gibbsite HTT at different temperatures and $\mathrm{pH}$ values of the aqueous suspension are shown in Fig. $2 \mathrm{a}$ and $\mathrm{b}$. The complete phase transformation of gibbsite to boehmite is carried out under hydrothermal conditions in an aqueous suspension and $\mathrm{pH}$ values of 6.0-10.5 at $190{ }^{\circ} \mathrm{C}$ after $180 \mathrm{~min}$, at $200{ }^{\circ} \mathrm{C}$ after $120 \mathrm{~min}$ and at $210{ }^{\circ} \mathrm{C}$ after $20 \mathrm{~min}$ (Fig. 2a). The phase transition to boehmite under hydrothermal conditions takes place with a noticeable induction period of $120 \mathrm{~min}$ at $180{ }^{\circ} \mathrm{C}$, which reduces to $20-30 \mathrm{~min}$ at 190-200 ${ }^{\circ} \mathrm{C}$ (Fig. 2a). The induction period appreciably lengthens with decreasing $\mathrm{pH}$ from 10.5 to $6.0-8.0$ at $190{ }^{\circ} \mathrm{C}$ in 2 times (from 30 to $60 \mathrm{~min}$ ) (Fig. 2b).

Three pronounced endothermic effects are distinguished on the DSC curves of the samples obtained: I - doubled beginning at $228-237$ and $284-353{ }^{\circ} \mathrm{C}$ with the temperature peaks in the intervals $256-292$ and $284-300{ }^{\circ} \mathrm{C}$, respectively; IIbeginning at $396-399{ }^{\circ} \mathrm{C}$ with the temperature peak in the interval $397-407{ }^{\circ} \mathrm{C}$; III-beginning at $488-514{ }^{\circ} \mathrm{C}$ and with a temperature peak in the range of 535-563 ${ }^{\circ} \mathrm{C}$ (Fig. 3a and b; Fig. 2a and b in the Supplementary Material).

According to the thermogravimetric (TG) analysis combined with the mass spectrometry (MS) method, mass losses in the I effect region vary from 1.6 to $28.3 \%$ by weight. They are caused by the water release during the dehydration of residual gibbsite in the case of its incomplete phase transformation. The III effect corresponds to the dehydration of the boehmite formed in $\gamma-\mathrm{Al}_{2} \mathrm{O}_{3}$ with the release of water in the range of $4.5-15.0 \%$ by weight. The occurrence of the II effect depends on the temperature and duration of the HTT. It appears in the DSC curves obtained during 60-90 min at $190{ }^{\circ} \mathrm{C}$ (Fig. 2a in the Supplementary Material), $30 \mathrm{~min}$ at $200{ }^{\circ} \mathrm{C}$ (Fig. $2 \mathrm{~b}$ in the Supplementary Material), $15 \mathrm{~min}$ at $210{ }^{\circ} \mathrm{C}$. II effect remains on DSC curves even with the gibbsite transformed into boehmite 


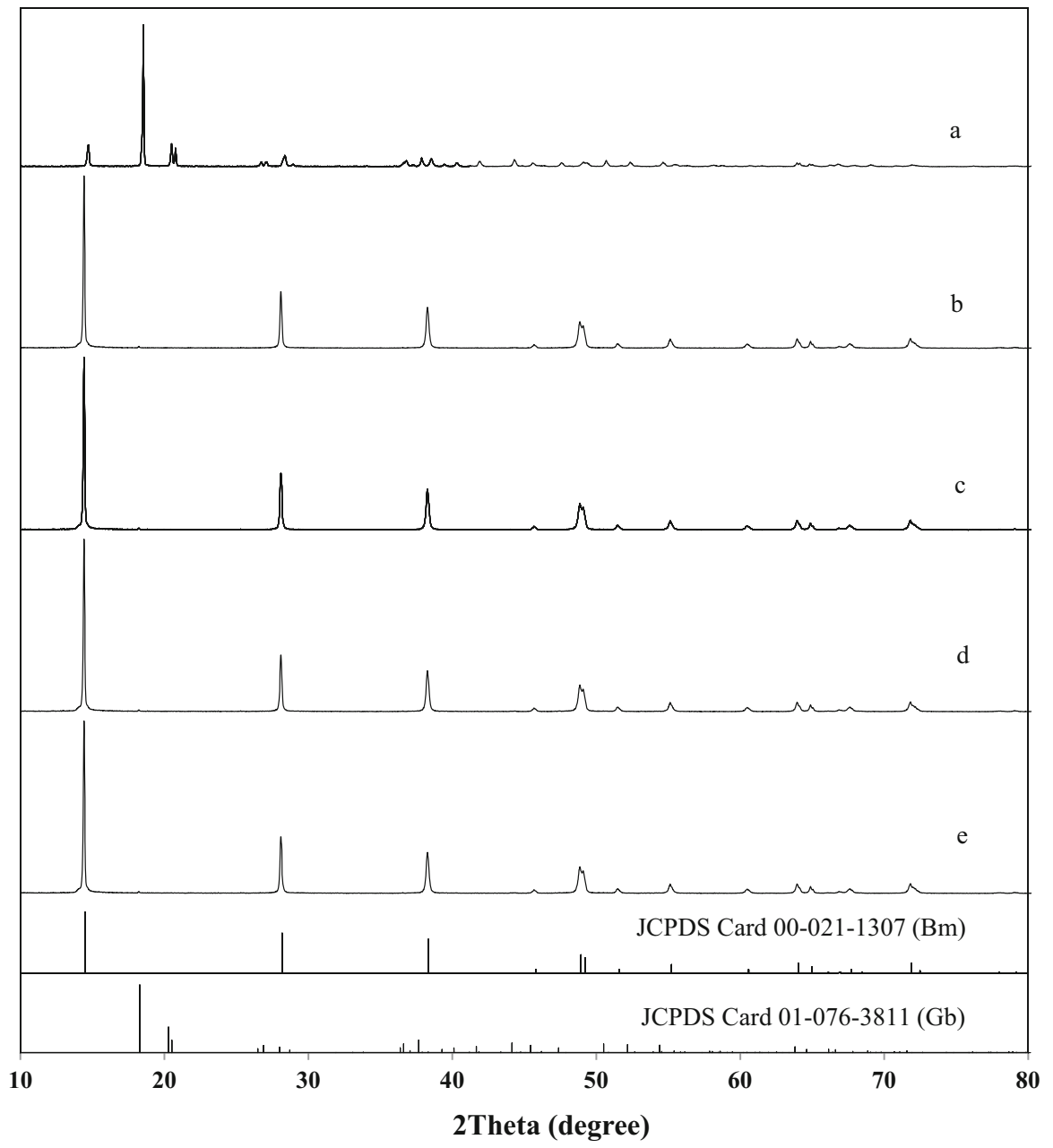

Fig. 1 XRD patterns of the product obtained by the gibbsite $\mathrm{HHT}$ of $\gamma-\mathrm{Al}(\mathrm{OH})_{3}$ at $\mathrm{T}=180{ }^{\circ} \mathrm{C}$, $\tau=180 \mathrm{~min}, \mathrm{pH} 10.5(\mathbf{a})$, at $\mathrm{T}=190{ }^{\circ} \mathrm{C}, \tau=180 \mathrm{~min}, \mathrm{pH} 8.0(\mathbf{b})$, at $\mathrm{T}=190{ }^{\circ} \mathrm{C}, \tau=180 \mathrm{~min}, \mathrm{pH} 8.0$ after heating to $400{ }^{\circ} \mathrm{C}\left(10{ }^{\circ} \mathrm{C} / \mathrm{min}\right)(\mathbf{c})$ and the products of gibbsite HTT in "dry steam" conditions at $\mathrm{T}=200{ }^{\circ} \mathrm{C}, \tau=5 \mathrm{~h}, \mathrm{P}=1.6 \mathrm{MPa}$ before $(\mathbf{d})$ and after $(\mathbf{e})$ heating up to $400{ }^{\circ} \mathrm{C}\left(10^{\circ} \mathrm{C} / \mathrm{min}\right)$

completely, when the weight loss observed on the TG-curves while the water is released in the region of the III effect reaches $15.0 \%$ of the mass (Fig. 3a), that is the stoichiometric amount at $100 \%$ of boehmite dehydration according to the reaction $\mathbf{2} \gamma$-AlOOH $\rightarrow \gamma-\mathbf{A l}_{2} \mathbf{O}_{3}+\mathbf{H}_{2} \mathbf{O}$. Moreover, the II effect is not related to the phase transformation of gibbsite or boehmite in $\gamma-\mathrm{Al}_{2} \mathrm{O}_{3}$. This can be seen by analyzing such samples subjected to additional heating up to $400{ }^{\circ} \mathrm{C}$ at a rate of $10{ }^{\circ} \mathrm{C} / \mathrm{min}$ with XRD and ${ }^{27} \mathrm{Al}$ NMR spectroscopy (Fig. 3a and b in the Supplementary Material). It then disappears on the DSC-curves and the III effect retains its position and the corresponding weight loss according to the TG data (Fig. 3b). 


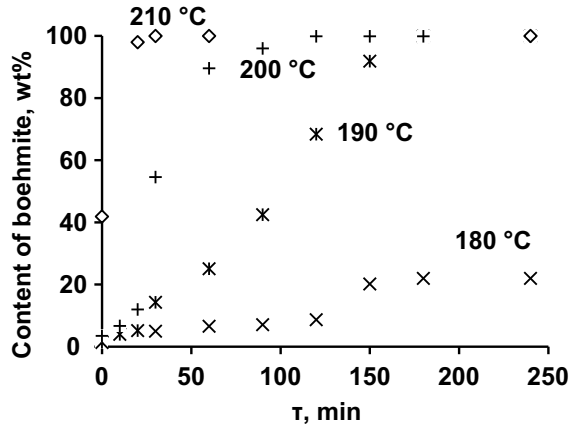

a

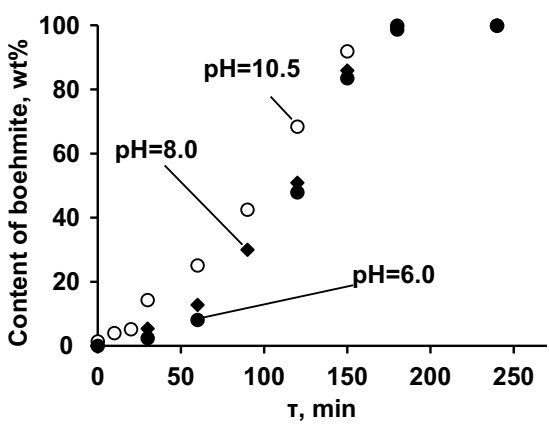

b

Fig. 2 Dependences of boehmite content on the duration $(\tau)$ of the gibbsite HTT at the different temperatures and $\mathrm{pH} 10.5(\mathbf{a})$, at $\mathrm{T}=190^{\circ} \mathrm{C}$ and various $\mathrm{pH}$ of the suspension (b)

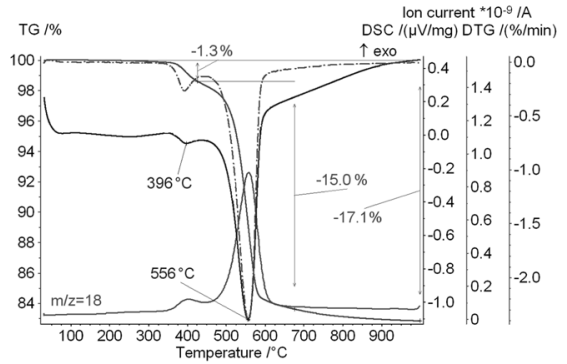

$\mathbf{a}$

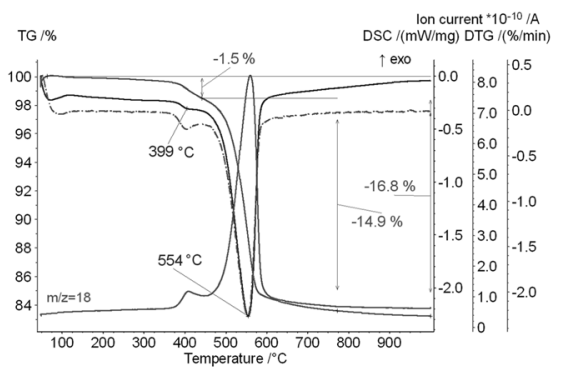

c

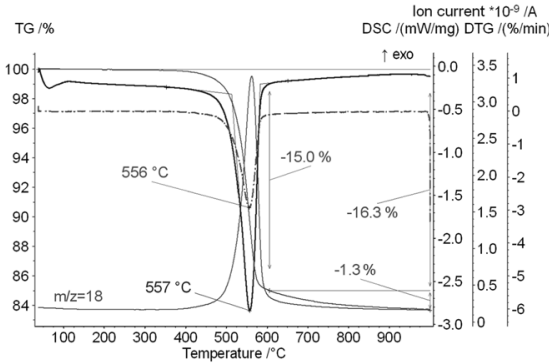

b

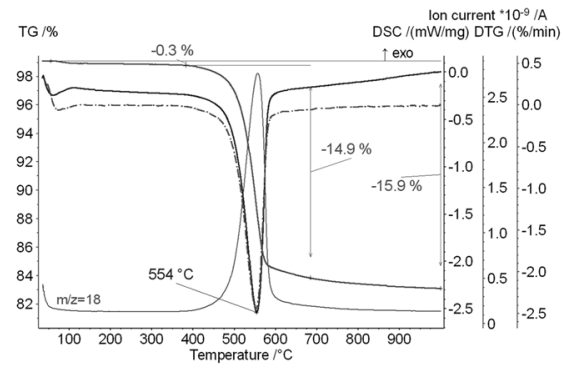

d

Fig. 3 The thermal curves of the products of gibbsite HTT in aqueous suspension, obtained at $190{ }^{\circ} \mathrm{C}$ (pH 8.0) during $180 \mathrm{~min}(\mathbf{a})$ and $190{ }^{\circ} \mathrm{C}\left(\mathrm{pH}\right.$ 8.0) during $180 \mathrm{~min}$ after heating up to $400{ }^{\circ} \mathrm{C}\left(10{ }^{\circ} \mathrm{C} / \mathrm{min}\right)$ (b), at $200{ }^{\circ} \mathrm{C}(\mathrm{P}=1.6 \mathrm{MPa})$ during $5 \mathrm{~h}$ before (c) and after heating up to $400{ }^{\circ} \mathrm{C}\left(10^{\circ} \mathrm{C} / \mathrm{min}\right)(\mathbf{d})$

The diffractograms of the samples show the lines specific for boehmite (Fig. 1b and c) and on the ${ }^{27} \mathrm{Al} \mathrm{NMR}$ spectra only the signals of aluminum atoms in the octahedral oxygen environment in the structure of aluminum hydroxide with a chemical shift of $\delta=15.0 \mathrm{ppm}$ are present (without the signals of aluminum atoms in the tetrahedral oxygen identified $\gamma-\mathrm{Al}_{2} \mathrm{O}_{3}$ ) (Fig. 3a-d in the Supplementary Material). According to the TG and MS analysis, the amount of water released in the 
region of the II effect is $1.1-1.8 \%$ by weight of its total amount released when the samples are heated to $1000{ }^{\circ} \mathrm{C}$. Such water can be encapsulated in the closed pores which are formed when the large crystals of boehmite coalesce together and form rhombi and parallelepipeds (Fig. 4a-4f in the Supplementary Material), when its concentration in samples exceeds $25 \%$ by mass (Fig. $2 \mathrm{a}$ and b). When the HTT is carried out in suspension gibbsite dissolves and aluminate ions are formed, which subsequently participate in the formation of the crystal-forming complexes and the boehmite buds. This is identified in the ${ }^{27} \mathrm{Al} \mathrm{NMR}$ spectra of the mother liquors of aluminum hydroxide suspensions collected after 30-60 min at 200 and $210^{\circ} \mathrm{C}$ and with various $\mathrm{pH}$ values (Table 1).

In the spectra of the mother liquors (Fig. 5a and b in the Supplementary Material) in addition to the signal with a chemical shift of $0.7 \mathrm{ppm}$ corresponding to aluminum cations in $\left[\mathrm{Al}\left(\mathrm{H}_{2} \mathrm{O}\right)_{6}\right]^{3+}$ complexes in an aqueous solution of $\mathrm{AlCl}_{3}$, which was used as an external standard, there is a signal with a chemical shift of $80.7 \mathrm{ppm}$ corresponding to aluminum in the anions $\left[\mathrm{Al}(\mathrm{OH})_{4}\right]^{-}[22-24]$. The concentrations of aluminum atoms in solutions were $0.01-1.06 \mathrm{mmol} / \mathrm{l}$ (Table 1). Gibbsite mostly dissolves which is seen by the behavior shown in Fig. 4. As the phase transformation of gibbsite into boehmite reaches $100 \%$ the concentration of aluminum atoms in the mother liquor changes insignificantly and the dependence of the boehmite content on the concentration of aluminum atoms in the solution acquires the form of a saturated curve.

Boehmite is formed by the incorporation of crystal-forming complexes during the interaction of mononuclear anions $\left[\mathrm{Al}(\mathrm{OH})_{4}\right]^{-}$with the surface layers of gibbsite $[22,23]$. Those are formed during the dehydration and intensive stratification of gibbsite crystals along the (001) plane and its hydroxylation, which is seen from the analysis of IR-spectra of the samples in the region of interlayer $\left(v(\mathrm{OH})=3528 \mathrm{~cm}^{-1}\right)$ and terminal $\left(\mathrm{v}(\mathrm{OH})=3624 \mathrm{~cm}^{-1}\right)$ stretching vibrations of hydroxyl groups located on the (001) plane (Fig. 5a and b; Fig. 6a and b in the Supplementary Material).

The ratio of the intensities of the above points on the initial gibbsite IR-spectrum is $\mathrm{I}_{3528} / \mathrm{I}_{3624}=1.82$. The ratio $\mathrm{I}_{3528} / \mathrm{I}_{3624}$ is reduced to 1.30 after the HTT in a sample containing only $5 \%$ (by weight) of boehmite the IR-spectrum of which is still very weakly manifested with valence vibrations of its structural hydroxyl groups $\left(\left(v_{\mathrm{s}}(\mathrm{OH})=3292 \mathrm{~cm}^{-1}\right.\right.$ and $\left.v_{\mathrm{as}}(\mathrm{OH})=3093 \mathrm{~cm}^{-1}\right)$ (Fig. 5a and b; Fig. 6a

Table 1 The effect of HTT gibbsite conditions on the chemical shift and concentration of aluminum atoms in the mother liquor according to ${ }^{27} \mathrm{Al}$ NMR

\begin{tabular}{lllll}
\hline \multicolumn{2}{l}{ HTT conditions } & & $\delta(\mathrm{ppm})$ & $\mathrm{C}(\mathrm{Al})(\mathrm{mmol} / \mathrm{l})$ \\
\cline { 1 - 2 } $\mathrm{T}\left({ }^{\circ} \mathrm{C}\right)$ & $\tau(\mathrm{min})$ & $\mathrm{pH}$ & & \\
\hline 200 & 30 & 10.5 & 80.7 & 0.08 \\
& 60 & & & 0.43 \\
& 60 & 8.0 & & 0.11 \\
& 60 & 6.0 & & 0.01 \\
210 & 30 & 10.5 & & 0.75 \\
& 60 & & & 1.06 \\
\hline
\end{tabular}


Fig. 4 Dependence of the aluminum atoms concentration in the mother liquor on the boehmite content in the products of gibbsite HTT at $200-210^{\circ} \mathrm{C}$ $(\mathrm{pH} 10.5)$

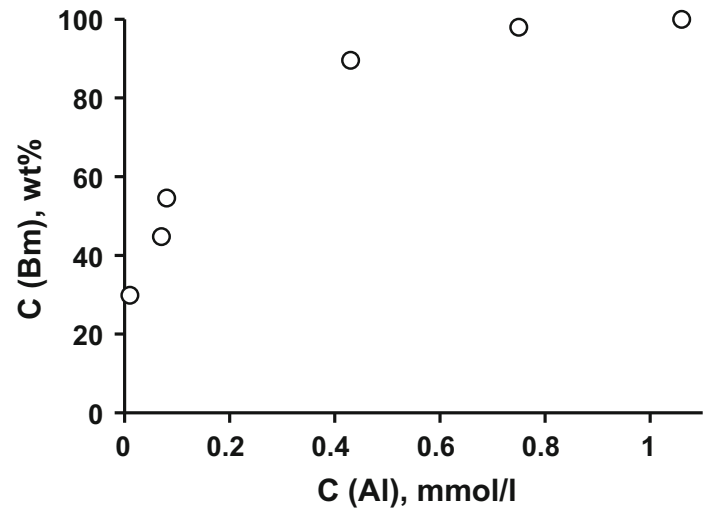

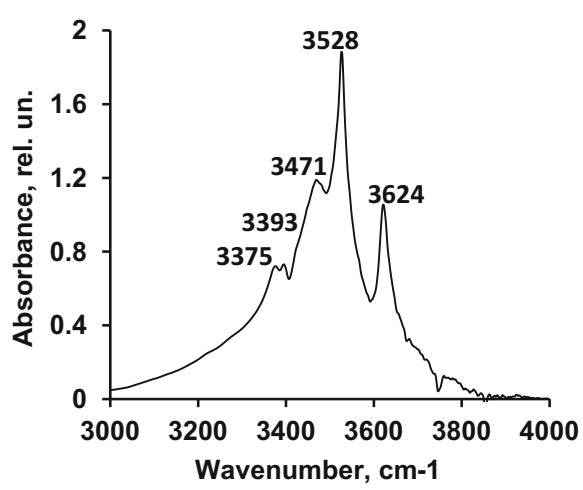

a

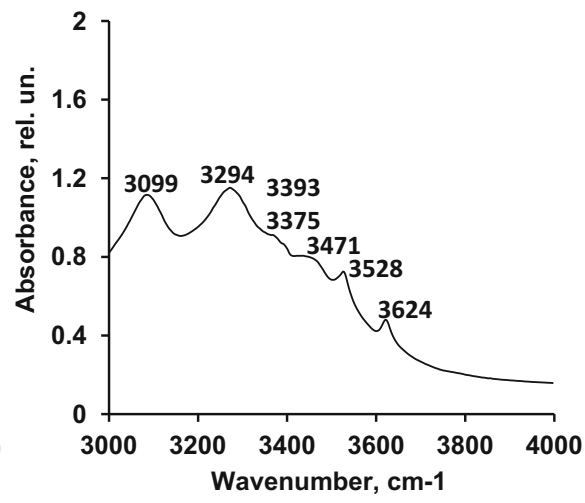

b

Fig. 5 IR spectra of the gibbsite (a) and the HTT products obtained at $190{ }^{\circ} \mathrm{C}$ and $\mathrm{pH} 10.5$ during $150 \min (\mathbf{b})$

and $b$ in the Supplementary Material). The increase in the proportion of terminal $\mathrm{OH}$ groups relative to the interlayer fraction may be due to enhanced hydroxylation of the (001) plane and an increase in the number of such planes which is facilitated by the dehydration of gibbsite. According to the SEM data (Fig. 4a-f in the Supplementary Material) of the agglomerate chips of the samples containing boehmite, gibbsite plates with thickness starting from $\sim 20-100 \mathrm{~nm}$ are parallel to each other, and between them rare cracks with a width of $\sim 10-50 \mathrm{~nm}$ are observed. The crystals of boehmite are precipitated and grow on the surface of such plates.

The exfoliation of gibbsite crystals and simultaneous formation of boehmite promotes an increase in the specific surface area from 0.5 to $1.5 \mathrm{~m}^{2} / \mathrm{g}$ mainly due to the formation of thin open mesopores (Table 2 and Figs. 8-15 in the Supplementary Material) with a diameter of $2.2-4.1 \mathrm{~nm}$.

An insignificant number of large mesopores formed with a diameter of $10.0-50.0 \mathrm{~nm}$ such as, likely, the interstices between the crystals of the formed 
Table 2 Parameters of the porous system of products of gibbsite HTT according to low-temperature adsorption of nitrogen (Bm-boehmite, $V_{p}$ - overall volume, $V_{\geq 4 n m}$ - volume of $\geq 4 \mathrm{~nm}, \mathrm{~S}_{\mathrm{p}}$ - specific surface area, $\mathrm{D}_{\max }$ - pore diameter on the maximum of $\mathrm{V}_{\mathrm{p}}, \mathrm{dV} / \mathrm{dD}$ - pore volume distribution by pore diameter for $\mathrm{D}_{\max }, \mathrm{D}_{\mathrm{av}}$ - average diameter)

\begin{tabular}{|c|c|c|c|c|c|c|c|c|c|}
\hline \multicolumn{3}{|c|}{ HTT conditions } & \multirow{2}{*}{$\begin{array}{l}\mathrm{C}(\mathrm{Bm}) \\
(\mathrm{wt} \%)\end{array}$} & \multirow{2}{*}{$\begin{array}{l}\mathrm{V}_{\mathrm{p}} \\
\left(\mathrm{cm}^{3} /\right. \\
\mathrm{g})\end{array}$} & \multirow{2}{*}{$\begin{array}{l}V_{\geq 4} \mathrm{~nm} \\
\left(\mathrm{~cm}^{3} / \mathrm{g}\right)\end{array}$} & \multirow{2}{*}{$\begin{array}{l}\mathrm{S}_{\mathrm{p}} \\
\left(\mathrm{m}^{2} /\right. \\
\mathrm{g})\end{array}$} & \multirow[t]{2}{*}{$\mathrm{D}_{\max }(\mathrm{nm})$} & \multirow{2}{*}{$\begin{array}{l}\mathrm{dV} / \mathrm{dD}\left(\times 10^{5}\right. \\
\left.\mathrm{cm}^{3} / \mathrm{g} \cdot \mathrm{nm}\right)\end{array}$} & \multirow{2}{*}{$\begin{array}{l}\mathrm{D}_{\mathrm{av}} \\
(\mathrm{nm})\end{array}$} \\
\hline $\begin{array}{l}\mathrm{T} \\
\left({ }^{\circ} \mathrm{C}\right)\end{array}$ & $\begin{array}{l}\tau \\
(\min )\end{array}$ & $\mathrm{pH}$ & & & & & & & \\
\hline \multirow{3}{*}{\multicolumn{3}{|c|}{ Initial gibbsite }} & - & $<0.01$ & $<0.01$ & $<0.5$ & 3.7 & 0.6 & 24.3 \\
\hline & & & & & & & 7.0 & 0.2 & \\
\hline & & & & & & & $\sim 10.0-50.0$ & 0.1 & \\
\hline \multicolumn{10}{|c|}{ «Dry steam » medium } \\
\hline \multirow[t]{10}{*}{200} & 300 & - & 99.3 & $<0.01$ & 0.01 & 2.6 & 2.1 & 151.6 & 11.3 \\
\hline & & & & & & & 3.0 & 106.6 & \\
\hline & & & & & & & 4.4 & 73.9 & \\
\hline & & & & & & & 5.4 & 24.0 & \\
\hline & & & & & & & $\sim 10.0-200.0$ & 6.1 & \\
\hline & $300^{\mathrm{a}}$ & - & 99.3 & 0.02 & 0.02 & 3.8 & 1.9 & 56.1 & 23.9 \\
\hline & & & & & & & 3.3 & 113.1 & \\
\hline & & & & & & & 4.0 & 255.9 & \\
\hline & & & & & & & 5.8 & 51.0 & \\
\hline & & & & & & & $\sim 10.0-200.0$ & 21.8 & \\
\hline \multicolumn{10}{|c|}{ Aqueous suspension medium } \\
\hline \multirow[t]{2}{*}{180} & 180 & 10.5 & 22.0 & $<0.01$ & $<0.01$ & 0.5 & 2.3 & 21.9 & 11.7 \\
\hline & & & & & & & $\sim 10.0-50.0$ & 2.3 & \\
\hline \multirow[t]{3}{*}{190} & 180 & 10.5 & 100.0 & 0.01 & $<0.01$ & 1.5 & 2.6 & 87.7 & 21.5 \\
\hline & & & & & & & 3.9 & 53.8 & \\
\hline & & & & & & & $\sim 20.0-300.0$ & 5.7 & \\
\hline \multirow[t]{7}{*}{190} & 180 & 8.0 & 100.0 & $<0.01$ & $<0.01$ & 0.8 & 1.7 & 86.0 & 13.2 \\
\hline & & & & & & & 3.9 & 28.2 & \\
\hline & & & & & & & $\sim 20.0-300.0$ & 3.5 & \\
\hline & $180^{\mathrm{a}}$ & & 100.0 & $<0.01$ & $<0.01$ & 2.4 & 2.0 & 105.9 & 11.0 \\
\hline & & & & & & & 2.3 & 77.0 & \\
\hline & & & & & & & 3.9 & 302.7 & \\
\hline & & & & & & & $\sim 20.0-300.0$ & 3.5 & \\
\hline \multirow[t]{3}{*}{190} & 180 & 6.0 & 98.7 & $<0.01$ & $<0.01$ & 1.0 & 2.3 & 39.0 & 34.5 \\
\hline & & & & & & & 4.1 & 36.4 & \\
\hline & & & & & & & $\sim 20.0-300.0$ & 2.1 & \\
\hline \multirow[t]{3}{*}{200} & 120 & 10.5 & 100.0 & $<0.01$ & $<0.01$ & 1.2 & 2.3 & 44.0 & 18.4 \\
\hline & & & & & & & 3.9 & 134.0 & \\
\hline & & & & & & & $\sim 20.0-200.0$ & 4.0 & \\
\hline
\end{tabular}


Table 2 continued

\begin{tabular}{|c|c|c|c|c|c|c|c|c|c|}
\hline \multicolumn{3}{|c|}{ HTT conditions } & \multirow{2}{*}{$\begin{array}{l}\mathrm{C}(\mathrm{Bm}) \\
(\mathrm{wt} \%)\end{array}$} & \multirow{2}{*}{$\begin{array}{l}\mathrm{V}_{\mathrm{p}} \\
\left(\mathrm{cm}^{3} /\right. \\
\mathrm{g})\end{array}$} & \multirow{2}{*}{$\begin{array}{l}V_{\geq 4} \mathrm{~nm} \\
\left(\mathrm{~cm}^{3} / \mathrm{g}\right)\end{array}$} & \multirow{2}{*}{$\begin{array}{l}\mathrm{S}_{\mathrm{p}} \\
\left(\mathrm{m}^{2} /\right. \\
\mathrm{g})\end{array}$} & \multirow[t]{2}{*}{$\mathrm{D}_{\max }(\mathrm{nm})$} & \multirow{2}{*}{$\begin{array}{l}\mathrm{dV} / \mathrm{dD}\left(\times 10^{5}\right. \\
\left.\mathrm{cm}^{3} / \mathrm{g} \cdot \mathrm{nm}\right)\end{array}$} & \multirow{2}{*}{$\begin{array}{l}\mathrm{D}_{\mathrm{av}} \\
(\mathrm{nm})\end{array}$} \\
\hline $\begin{array}{l}\mathrm{T} \\
\left({ }^{\circ} \mathrm{C}\right)\end{array}$ & $\begin{array}{l}\tau \\
(\min )\end{array}$ & $\mathrm{pH}$ & & & & & & & \\
\hline \multirow[t]{7}{*}{210} & 30 & 10.5 & 100.0 & $<0.01$ & $<0.01$ & 0.9 & 2.4 & 35.3 & 24.0 \\
\hline & & & & & & & 3.9 & 43.3 & \\
\hline & & & & & & & $\sim 8.0-200.0$ & 6.6 & \\
\hline & $30^{\mathrm{a}}$ & & 100.0 & $<0.01$ & $<0.01$ & 6.3 & 2.1 & 163.8 & 4.4 \\
\hline & & & & & & & 2.3 & 71.2 & \\
\hline & & & & & & & 3.9 & 227.6 & \\
\hline & & & & & & & $\sim 8.0-200.0$ & 10.1 & \\
\hline
\end{tabular}

${ }^{\mathrm{a}}$ After additional heating up to $400{ }^{\circ} \mathrm{C}\left(10^{\circ} \mathrm{C} / \mathrm{min}\right)$

boehmite and the gap between the (001) planes in gibbsite crystals do not have a noticeable effect on the pore volume of the images. After additional heating up to $400{ }^{\circ} \mathrm{C}\left(10^{\circ} \mathrm{C} / \mathrm{min}\right)$ the additional pores with a diameter of $3.9 \mathrm{~nm}$ appear. As shown in Table 2, the intensity of the corresponding maximum on the differential curve increases by 5.3-10.7 times because encapsulated water is distributed predominantly in the closed mesopores with a diameter of less than $4 \mathrm{~nm}$. After heating the new mesopores with a diameter of $2.1 \mathrm{~nm}$ appear in a sample synthesized at $210{ }^{\circ} \mathrm{C}$ for $0.5 \mathrm{~h}(\mathrm{pH} 10.5)$. Opening of closed mesopores causes an increase in the specific surface area of 3.0-7.0 times and a decrease in the average pore diameter in the samples.

Similarly, encapsulated water in closed pores is formed in the samples obtained under HTT with "dry steam" conditions. Thus, the isolation of encapsulated water on the DSC curves of boehmite samples synthesized under "dry steam" conditions at $200{ }^{\circ} \mathrm{C}$ for 300 and $540 \mathrm{~min}$ is manifested by a pronounced endothermic effect with a beginning at $381-390{ }^{\circ} \mathrm{C}$ and a temperature peak at $399-400{ }^{\circ} \mathrm{C}$ (Fig. $3 \mathrm{c}$ and d).

According to TG and MS analysis its amount reaches $1.5 \%$ by weight. This effect, same as in the samples obtained in the aqueous suspension, disappears after additional heating of the samples to $400{ }^{\circ} \mathrm{C}$ without the phase transformation of boehmite $\rightarrow \gamma-\mathrm{Al}_{2} \mathrm{O}_{3}$ (Fig. 1d and e; Fig. 3a-d in the Supplementary Material). The encapsulated water is distributed in mesopores with a diameter of $\geq 4 \mathrm{~nm}$, the volume of which after its isolation, for example, in a sample synthesized at $200{ }^{\circ} \mathrm{C}$ for $300 \mathrm{~min}$ increases almost by 2 (Table 2). That contributes to an increase in both the total pore volume and the average pore diameter, and also the specific surface area. The specific surface area increases by a factor of 1.5 due to the appearance of additional mesopores with a diameter of 4.0-4.4 nm and 5.4-5.8 nm. Its intensity on differential pore volume distribution curves increases by 3.5 and 2.1, and also in the range of pore diameters $\sim 10.0-200.0 \mathrm{~nm}$, which intensity increased by 3.6 (Table 2).

Thus, we can suggest the following sequence for the recrystallization of gibbsite in boehmite under hydrothermal conditions in an aqueous suspension (Fig. 7 in the 
Supplementary Material). At $\mathrm{T}=180^{\circ} \mathrm{C}$ or short treatment times at $\mathrm{T}=190-200{ }^{\circ} \mathrm{C} \quad(\mathrm{P}=1.0-1.6 \mathrm{MPa})$, the phase transformation of gibbsite to boehmite is carried out by dehydration and delamination of the crystals along the (001) plane to form plates of size $\sim 20-100 \mathrm{~nm}$ and cracks between them with a width $\sim 10-50 \mathrm{~nm}$, further gibbsite dissolution along the (002) and (110) planes. $\left[\mathrm{Al}(\mathrm{OH})_{4}\right]^{-}$anions, which interact with protons of hydroxyl groups on the $(001)$ planes, are released into the aqueous solution, which leads to the formation of boehmite nucleus and further growth of the crystals. The phase transformation of gibbsite to boehmite proceeds in a similar manner at the increasing of HTT duration at $\mathrm{T}=190-200{ }^{\circ} \mathrm{C}$ and temperature to $210{ }^{\circ} \mathrm{C}$ with the corresponding saturated water vapor pressure is up to $1.9 \mathrm{MPa}$. However, not only small ones are subjected to dehydration, delamination and dissolution, but also larger particles of gibbsite with following nucleation and growth of boehmite crystals up to $\sim 4 \mu \mathrm{m}$, which do not form strong crystallization bonds among themselves in the floccules volume.

The similarity of patterns of the changes in the porous system of samples synthesized by hydrothermal treatment of gibbsite both in aqueous suspension and in "dry steam" conditions allow one to suggest the same mechanism of dissolutionreprecipitation during the nucleation and growth of boehmite crystals. In the latter case the dissolution of gibbsite and the formation of $\left[\mathrm{Al}(\mathrm{OH})_{4}\right]^{-}$anions, as the sources of crystal-forming complexes and boehmite nuclei, probably happens in the near-the-surface layers of crystals.

\section{Conclusions}

In the porous boehmite system, which crystallizes under the hydrothermal treatment of gibbsite in aqueous suspension and in the "dry steam" conditions, closed mesopores are formed along the open ones.

The closed mesopores are cavities formed during the coalescence of large boehmite crystals in the form of rhombi and parallelepipeds by the mechanism of phase transformation gibbsite $\rightarrow$ boehmite through dissolution-reprecipitation.

Under the hydrothermal treatment of gibbsite in aqueous suspension the closed mesopores are formed with the diameters less than $4 \mathrm{~nm}$, dissecting which by heating to $400{ }^{\circ} \mathrm{C}$ increases the specific surface area by 3.0-7.0 times without changing the total pore volume. Under the conditions of "dry steam" the closed mesopores are formed with the diameters in the ranges of 4.0 to $\sim 6.0 \mathrm{~nm}$ and $\sim 10-200 \mathrm{~nm}$. When they are opened by heating up to $400{ }^{\circ} \mathrm{C}$, the specific surface area and pore volume increase by a factors of 1.5 and 2 times.

The process of phase transformation of gibbsite into boehmite is carried out by the dissolution-re-precipitation mechanism after intensive delamination of gibbsite crystals along the (001) plane with the formation of a multitude of layers with a thickness of $\sim 20-100 \mathrm{~nm}$ and cracks between them with a width $\sim 10-50 \mathrm{~nm}$. At $\sim 100 \%$ of boehmite content obtained under the investigated conditions, the specific surface area provided by the closed mesopores is $1.2-5.4 \mathrm{~m}^{2} / \mathrm{g}$. 
Acknowledgements The work was performed according to the Russian Government Program of Competitive Growth of Kazan Federal University.

Open Access This article is distributed under the terms of the Creative Commons Attribution 4.0 International License (http://creativecommons.org/licenses/by/4.0/), which permits unrestricted use, distribution, and reproduction in any medium, provided you give appropriate credit to the original author(s) and the source, provide a link to the Creative Commons license, and indicate if changes were made.

\section{References}

1. IUPAC Manual of Symbols and Terminology (1972) Pure Appl Chem 31:577

2. Auxilio AR, Andrews PC, Junk PC, Spiccia L, Neumann D, Raverty W, Vanderhoek N, Pringle JM (2008) J Mater Chem 18:2466

3. Park IS, Kwon MS, Kim N, Lee JS, Kang KY, Park J (2005) Chem Com 3:5667-5669

4. Soares AVH, Perez G, Passos FB (2016) Appl Catal B 185:77-87

5. Teixeira M, Rodrigues SC, Campo M, Pacheco Tanaka DA, Llosa Tanco MA, Madeira LM, Sousa JM, Mendes A (2014) Chem Eng Res Des 92:2668-2680

6. Abu-Elella R, Ossman ME, Abd-Elfatah M, Elgendi A (2013) Desalin Water Treat 51:3472-3481

7. Egorova SR, Mukhamed'yarova AN, Lamberov AA (2015) Russ J Appl Chem 88:805-811

8. Musić S, Dragčević D, Popović S (1999) Mat Let 40:269-274

9. Levin I, Brandon D (2005) J Am Ceram Soc 81:1995-2012

10. Moroz EM, Shefer KI, Zyuzin DA, Ivanova AS, Kulko EV, Goidin VV, Molchanov VV (2006) React Kinet Catal L 87:367-375

11. Yang Y, Xu Y, Han B, Xu B, Liu X, Yan Z (2016) J Colloid Interface Sci 469:1-7

12. Hwang KT, Lee HS, Lee SH, Chung KC, Park SS, Lee JH (2001) J Eur Ceram Soc 21:375-380

13. Inoue M, Kominami H, Inui T (1990) J Am Ceram Soc 73:1100-1102

14. Yoldas BE (1973) J Appl Chem Biotech 23:803-809

15. Liu Y, Jia L, Hou B, Li D (2015) Bull Korean Chem Soc 36:2851-2861

16. Mehta SK, Kalsotra A, Murat M (1992) Thermochim Acta 205:191-203

17. Tsuchida T (2000) J Eur Ceram Soc 20:1759-1764

18. Lopushan VI, Kuznetsov GF, Pletnev RN, Kleshchev DG (2007) Bull Russ Acad Sci Phys 71:1187-1189

19. Oh CJ, Yi YK, Kim SJ, Tran T, Kim MJ (2013) Powder Technol 235:556-562

20. Panasyuk GP, Belan VN, Voroshilov IL, Kozerozhets IV (2010) Inorg Mater 46:747-753

21. Costa TMH, Gallas MR, Benvenutti EV, da Jornada JAH (1999) J Phys Chem B 103:4278-4284

22. Mathieu Y, Rigolet S, Valtchev V, Lebeau B (2008) J Phys Chem C 112:18384-18392

23. Panias D, Asimidis P, Paspaliaris I (2001) Hydrometallurgy 59:15-29

24. Satokawa S, Osaki Y, Samejima S, Miyawaki R, Tomura S, Shibasaki Y, Sugahara Y (1994) Clays Clay Miner 42:288-297

25. Filho RWND, Rocha GA, Montes CR, Vieira-Coelho AC (2016) Mater Res 19:659-668

26. Inoue M, Kitamura K, Tanino H, Nakayama H, Inui T (1989) Clays Clay Miner 37:71-80 